\title{
Phosphorus-iron interaction in sediments: can an electrode minimize phosphorus release from sediments?
}

\author{
Gilberto Martins • Luciana Peixoto • \\ António G. Brito • Regina Nogueira
}

Published online: 15 June 2014

(C) Springer Science+Business Media Dordrecht 2014

\begin{abstract}
All restoration strategies to mitigate eutrophication depend on the success of phosphorus (P) removal from the water body. Therefore, the inputs from the watershed and from the enriched sediments, that were the sink of most $\mathrm{P}$ that has been discharged in the water body, should be controlled. In sediments, iron (hydr)oxides minerals are potent repositories of $\mathrm{P}$ and the release of $\mathrm{P}$ into the water column may occur upon dissolution of the iron (hydr)oxides mediated by iron reducing bacteria. Several species of these bacteria are also known as electroactive microorganisms and have been recently identified in lake sediments. This capacity of bacteria to transfer electrons to electrodes, producing electricity from the oxidation of organic matter, might play a role on P release in sediments. In the present work it is discussed the relationship between phosphorus and iron cycling as well as the application of an electrode
\end{abstract}

G. Martins $(\bowtie) \cdot$ L. Peixoto

CEB - Centre of Biological Engineering, University of Minho, Campus de Gualtar, 4710-057 Braga, Portugal e-mail: gilberto.martins@deb.uminho.pt

A. G. Brito

Department of Biosystems Sciences and Engineering, Institute of Agronomy, University of Lisbon, Tapada da Ajuda, 1349-017 Lisbon, Portugal

R. Nogueira

Institute of Sanitary Engineering and Waste Management, University of Hannover, Welfengarten 1,

30167 Hannover, Germany to work as external electron acceptor in sediments, in order to prevent metal bound $\mathrm{P}$ dissolution under anoxic conditions.

Keywords Bioelectricity - Biogeochemical processes - Eutrophication - Phosphorus cycling · Sediment bacterial community

\section{Phosphorus and eutrophication}

\subsection{Impact of eutrophication on water quality}

Phosphorus $(\mathrm{P})$ concentrations in soil and freshwater systems have increased by at least $75 \%$ during the last decades, and the estimated flow of $\mathrm{P}$ from the total land area to the ocean has risen to 22 million tons per year (Bennett et al. 2001). This amount exceeds the world's annual consumption of P fertilizer, estimated around 15 million tones (Cordell et al. 2012). While much of the $\mathrm{P}$ accumulated in terrestrial systems would eventually be available for plant growth, there is no practical way to recover $\mathrm{P}$ lost to aquatic systems.

In aquatic systems too much $\mathrm{P}$ and nitrogen result in eutrophication, which promotes excessive algal and aquatic plant growth along with undesirable impacts on biodiversity (the destruction of communities and elimination of the less competitive), water quality (production of cyanotoxins), fish stocks and the recreational value of the environment. Algal blooms 
can include species that release toxins harmful to humans or animals, while decomposition of algae can lower dissolved oxygen levels, causing mass mortality among fish (Carpenter 2005). Eutrophication of surface waters bodies results mainly from anthropogenic activities occurring in watersheds-extensive fertilization and domestic or industrial sewage discharges without removal of nutrients (especially P)—and is one of the most significant and unresolved problems with respect to water resource protection (Martins et al. 2008; Conley et al. 2009). Many of the world largest freshwater lakes are eutrophic, including Lake Erie (United States), Lake Victoria (Tanzania/ Uganda/Kenya), and Tai Lake (China) (Selman and Greenhalgh 2009). Moreover, all 217 lakes included in the International Lake Environment Committee survey showed an increase in the level of eutrophication over the past 50 years (UNEP 2012). Eutrophication of European lakes and reservoirs is a severe problem and is the main reason why the status of these bodies of water is deemed unsatisfactory under the rules of the Water Framework Directive (WFD 2000/60EC; Martins et al. 2013). Thus, finding a solution to the problem of eutrophication in developing countries is urgent because, as time passes, stopping eutrophication becomes more difficult and expensive every year (UNEP 2012). As an example, the estimated costs of the damage caused by freshwater eutrophication in the UK were around 85-130 million euros per year plus 61 million euros per year of costs incurred in designing of measures to combat eutrophication (Pretty et al. 2003).

\subsection{Sediments as a source of phosphorus}

Before the decade of 1980-1990, the reason for eutrophication was considered to be the $\mathrm{P}$ rich municipal wastewater discharge into surface waters. Therefore, billions of euros were invested in improving wastewater treatment and other pollution-combating measures with the expectation that these measures would solve the eutrophication problem (Søndergaard et al. 2007). Despite the instituted control measures, eutrophication remains a major problem, either because external loading was not reduced sufficiently, or because chemical and/or biological processes in affected lakes delayed or prevented recovery (Søndergaard et al. 2003, 2007). In fact, it has become recognized that eutrophication is not only caused by agricultural fertilization, but also by decades of $\mathrm{P}$
Table 1 Typical values for $\mathrm{P}$ chemical forms in lake sediments

\begin{tabular}{lll}
\hline P form & $\begin{array}{l}\text { Lake Fogo } \\
\text { (oligotrophic } \\
\text { lake) } / \% \text { of } \\
\text { total P }\end{array}$ & $\begin{array}{l}\text { Lake Verde } \\
\text { (eutrophic } \\
\text { lake)/\% } \\
\text { of total P }\end{array}$ \\
\hline Labile P & 2 & 11 \\
Metal bound P & 19 & 36 \\
Organic P & 15 & 28 \\
Ca-bound P & 16 & 9 \\
Refractory/residual P & 48 & 17 \\
\hline
\end{tabular}

accumulation in aquatic sediments, one of the main sources of $\mathrm{P}$ in the water column (Martins et al. 2008; UNEP 2012). A recent examination of long-term data collected from 35 lakes in Europe and North America led to the conclusion that $\mathrm{P}$ release from the lake sediments continues typically for 10-15 years after reduction of $\mathrm{P}$ loading to the lakes (Jeppesen et al. 2005), but in some lakes may last for more than 20 years (Søndergaard et al. 2003).

In most lakes, the major $\mathrm{P}$ input is of organic origin and is the result of lake primary production and catchment (Pettersson 2001). Particulate organic P that reaches sediments is mineralized and the released phosphate ions are easily adsorbed by minerals [as for example, iron (Fe) and aluminium (Al) oxides, clay minerals with surficial $\mathrm{Fe}$ and $\mathrm{Al}$ (hydr)oxides, and possibly also manganese $(\mathrm{Mn})$ oxides] or stored by microorganisms (Gonsiorczyk et al. 1998). As an example, Table 1 presents $P$ distribution in sediments from two Azorean lakes with distinct trophic states. In the sediment of the oligotrophic lake, $\mathrm{P}$ was mostly refractory/residual, whereas in the eutrophic lake, $64 \%$ of the total P was organically bound and metal oxide-bound in the sediment (Ribeiro et al. 2008; Martins et al. 2008).

Sediments can act as an internal source of $\mathrm{P}$ to the overlying water. The Fe (hydr)oxide minerals are potent repositories of phosphate, and the release of phosphate into pore water may occur upon dissolution of the Fe (hydr)oxides mediated by a number of biotic processes (Lentini et al. 2012). Several processes have been proposed to explain this phenomenon. The pioneering work of Einsele (1936), later adapted by Mortimer (1941, 1942), focused on the pool of $P$ bound to $\mathrm{Fe}(\mathrm{III})$ oxides and proposed that $\mathrm{P}$ is released 
Fig. 1 Simplified hypothetical diagram of the biogeochemical processes carried out by bacteria in sediments (adapted from Nealson 1997). AOB ammonium oxidizing bacteria, $N O B$ nitrite oxidizing bacteria, $D N B$ denitrifying bacteria, $M R B$ manganese reducing bacteria, $I R B$ iron reducing bacteria, $S R B$ sulphate reducing bacteria, $M G B$ methanogenic bacteria

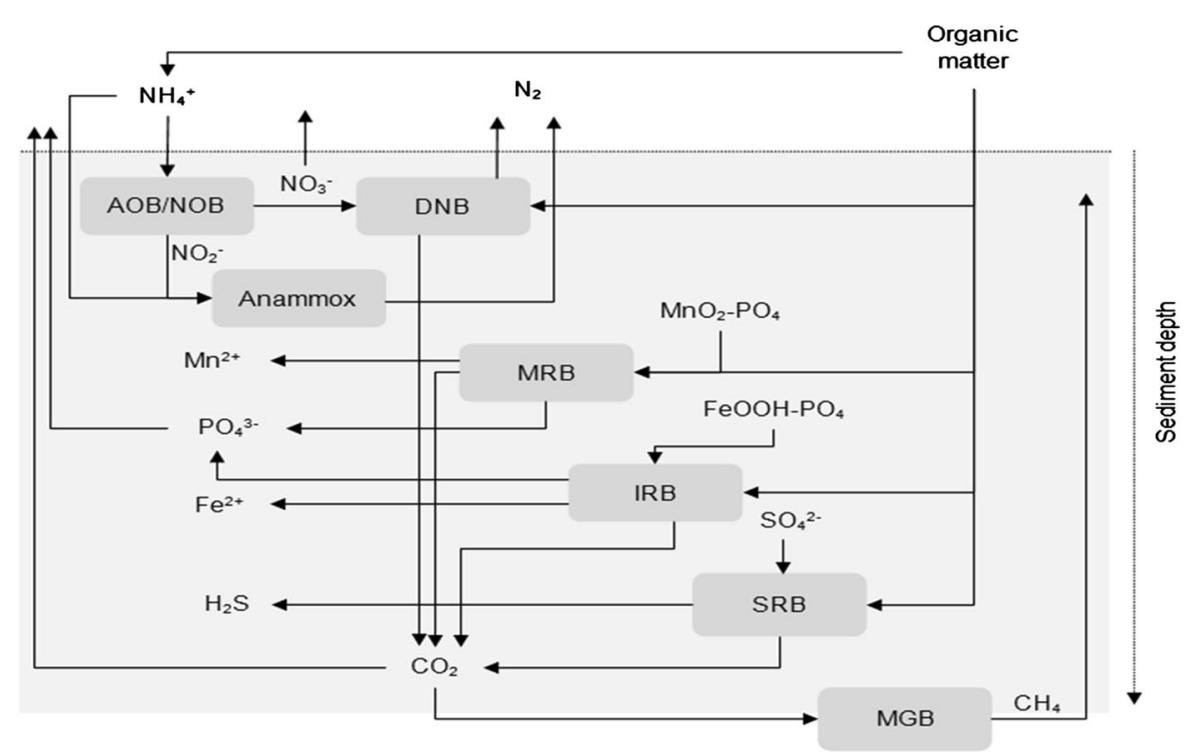

from sediments when the insoluble Fe(III) oxides are reduced under anoxic conditions. However, no experimental evidence was presented in support of this proposal (Golterman 2001). Several later studies suggested that this process is more complex than previously described, involving the participation of several bacterial groups (Khoshmanesh et al. 2002; Azzoni et al. 2005; Hupfer and Lewandowski 2008). Therefore, the eutrophication problem is yet to be solved, and because a good management of lake watershed will not be enough (the so-called external measures) to revert the eutrophication state in many lakes, solutions in the water body itself (internal measures) are in much need, but are not really available.

\section{Sediment biogeochemical processes}

\subsection{General description}

Sediments as repositories of the overlying water body (for example, ocean, lake, river or reservoir) are composed of organic and inorganic materials (Huettel et al. 2003; Chen and White 2004) and shelter a complex microbial ecosystem that thrives on several different electron donors and acceptors (Martins et al. 2011, 2012). Microorganisms in sediments mediate several processes in the biogeochemical cycles of carbon, nutrients, metals, and sulphur (Nealson 1997; Wobus et al. 2003; Raghoebarsing et al. 2006). Figure 1 shows a simplified scheme of the microbial processes occurring in sediments and Fig. 2 depicts the respective relevant biological reactions. The oxidation of organic matter settled from the water column into sediments is coupled to a succession of increasingly less energetically-favourable terminal electron acceptors; that is, $\mathrm{O}_{2}$, $\mathrm{NO}_{3}{ }^{-}, \mathrm{Mn}(\mathrm{IV}), \mathrm{Fe}(\mathrm{III})$, and $\mathrm{SO}_{4}^{-2}$, resulting in a vertical pattern of redox stratification (Thomsen et al. 2004; Canavan et al. 2006; Himmelheber et al. 2009).

The oxygen reduction zone in sediments can extend from millimetres to centimetres depending on carbon consumption (Himmelheber et al. 2008). In the top sediment layers, ammonium derived from the ammonification of organic matter or dissimilatory nitrate reduction, is autotrophically oxidized in the presence of oxygen to nitrate via nitrite, in a two step-process called nitrification (Figs. 1, 2). Ammonium oxidizing bacteria (AOB) and nitrite oxidizing bacteria (NOB), collectively known as nitrifiers, compete with carbon oxidizers in top sediment layers for oxygen (Altmann et al. 2004; Himmelheber et al. 2009). Nitrate resulting from the activity of nitrifiers diffuses into the nitrate reduction zone and is used as terminal electron acceptor in the oxidation of organic carbon by facultative heterotrophic bacteria, under suboxic conditions (Fig. 1); that is oxygen concentrations below $2 \mathrm{mg} \mathrm{L}^{-1}$ (Fennel et al. 2009). This process called denitrification occurs in several steps with the formation of distinct intermediates $\left(\mathrm{NO}_{2}{ }^{-}, \mathrm{NO}, \mathrm{N}_{2} \mathrm{O}\right)$, being 
Fig. 2 Main biogeochemical reactions that occur in sediments

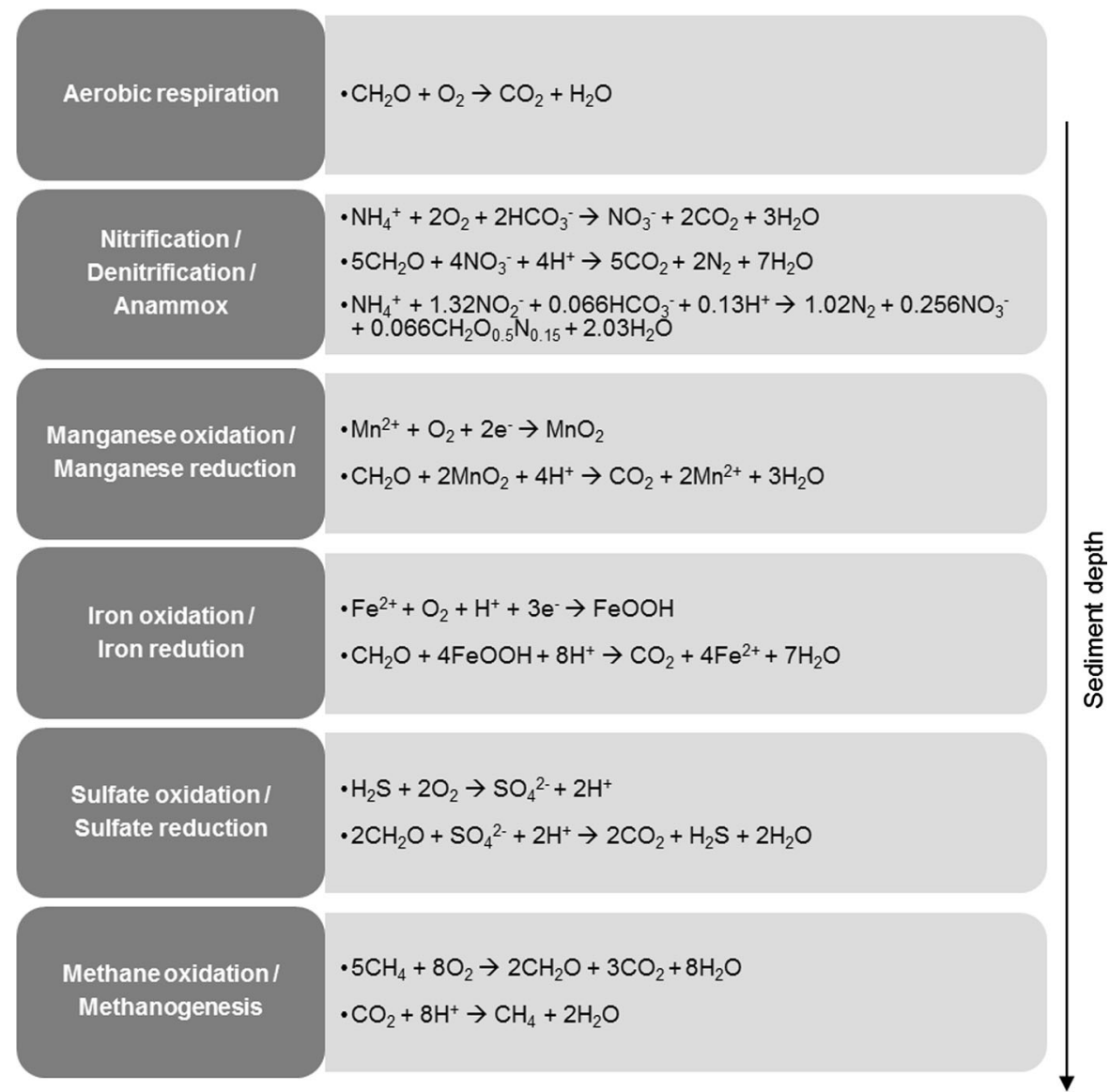

nitrogen gas the end product (Fig. 2). As an alternative, the autotrophic nitrogen removal over nitrite done by anaerobic AOB, designated as anammox bacteria (Figs. 1,2), might account for at least $50 \%$ of $\mathrm{N}_{2}$ losses from sediments, which have previously been entirely attributed to denitrifying bacteria (Thamdrup and Dalsgaard 2002; Dalsgaard et al. 2005). Deeper in sediments, $\mathrm{Fe}(\mathrm{III})$ and $\mathrm{Mn}(\mathrm{IV})$ oxides present in the metal reduction zone are reduced by iron reducing bacteria (IRB) and manganese reducing bacteria (MRB), using the remaining organic compounds or hydrogen as electron donors, as presented in Fig. 2 (Lovley and Phillips 1987; Nealson 1997; Lovley et al. 2004). Below the zone of metal reduction, the presence of sulphide in pore water is the result of the reduction of sulphate by sulphate reducing bacteria (SRB), as depicted in Fig. 1 (Nealson 1997). SRB oxidize lactate and ethanol to acetate, carbon dioxide and hydrogen (Muyzer and Stams 2008). Hydrogen is efficiently removed by hydrogen-consuming methanogens that grow syntrophically with SRB (Bryant et al. 1977; Muyzer and Stams 2008). Sulphate reduction can account for more than $50 \%$ of the organic carbon mineralization in marine sediments (Muyzer and Stams 2008). Finally, the organic matter turnover ends with methanogens that produce $\mathrm{CH}_{4}$ mostly by reduction of the methyl group of acetate or by the reduction of $\mathrm{CO}_{2}$ (Ferry and Lessner 2008). Nevertheless, the diagrammatic representation present in Fig. 1 is an oversimplification because of the existence of overlaps and microniches between different redox zones (Martins et al. 2011). This overlap is the result of resuspension and bioturbation as well as the formation of gas bubbles, feeding tubes and burrows from benthic fauna, resulting in a more rapid decomposition of organic matter than simple unidirectional redox changes (Kemp et al. 1990; Stockdale et al. 2009; Martins et al. 2011).

Through microbial metabolism based on redox reactions and syntrophic interactions, the manganese, 
iron, and sulfur cycles can influence nitrogen, carbon and $\mathrm{P}$ cycling and indirectly regulate nutrient availability for net primary production (Azzoni et al. 2005; Burgin et al. 2011). In the next section, it is discussed the role of $\mathrm{Fe}(\mathrm{III})$ reduction on the release of $\mathrm{P}$ from sediments.

\subsection{Iron reduction and phosphorus cycling}

Given the ubiquity of Fe (hydr)oxides within soils and sedimentary systems, microbial Fe(III) reduction can have a strong impact on carbon cycling and degradation. In fact, microbial Fe(III) reduction might be responsible for $50 \%$ of carbon oxidation in nonsulfidogenic sediments (Canfield et al. 1993; Thamdrup 2000). The biotic mechanisms of Fe(III) reduction are primarily attributed to either an indirect consequence of fermentation or microbial respiration, in which organisms couple the oxidation of carbon or molecular hydrogen to the reduction of $\mathrm{Fe}(\mathrm{III})$ for energy conservation (dissimilatory reduction by IRB). Particularly, in freshwater lakes with low sulphate concentrations, microbial $\mathrm{Fe}(\mathrm{III})$ reduction is an important process in the anaerobic degradation of organic matter (Thamdrup 2000; Lovley et al. 2004). Besides, IRB are also involved in the bioremediation of subsurface environments contaminated with heavy metals (Petrie et al. 2003) as well as harvesting electricity from aquatic sediments (Lovley et al. 2004; Martins et al. 2010, 2014).

Regarding the processes contributing to $\mathrm{P}$ dissolution in the pore water, one of the most important is the dissimilatory $\mathrm{Fe}(\mathrm{III})$ (hydr)oxides reduction (Einsele 1936; Mortimer 1941, 1942; Azzoni et al. 2005). It was already shown a direct relationship between redox conditions and the release of $\mathrm{P}$ from sediments (Rozan et al. 2002; Gächter and Müller 2003). Rozan et al. (2002) followed monthly the concentration of both solid and soluble $\mathrm{P}$ in sediments from a shallow coastal bay, and reported a marked decrease in the reactive solid $\mathrm{P}$ and a sharp increase in soluble $\mathrm{P}$ in the overlying water, as the conditions became more reducing throughout the summer months. Besides, it was observed a decrease in the amorphous $\mathrm{Fe}$ (III) and total Fe(III) (hydr)oxides pools and an increase in solid iron sulphide $(\mathrm{FeS})$ and pyrite $\left(\mathrm{FeS}_{2}\right)$ (Rozan et al. 2002; Chacon et al. 2006). In sulphate-rich sediments, hydrogen sulphide, resulting from sulphate reduction by SRB, reduces Fe(III) and the released $\mathrm{Fe}$ (II) precipitates as insoluble FeS that adsorb
$\mathrm{P}$ poorly at neutral $\mathrm{pH}$ (Nielsen et al. 2010). As a consequence, the sediment binding capacity towards $\mathrm{P}$ is reduced and the continuous release of phosphate from sediments may enhance the trophic status of water bodies (Holmer and Storkholm 2001; Rozan et al. 2002; Azzoni et al. 2005).

\subsection{Phylogeny and abundance of IRB}

$\mathrm{Fe}(\mathrm{III})$ reduction is widespread in nature being IRB represented by many different types of Bacteria and Archaea that are phylogenetically and physiologically diverse (Lovley et al. 2004; Lin et al. 2007; Li et al. 2011). However, most of current knowledge about the mechanisms and ecological importance of microbial $\mathrm{Fe}(\mathrm{III})$ reduction stems from studies focusing on Geobacter and Shewanella genera (Klueglein et al. 2013). Members of the Geobacteraceae family grow using acetate or hydrogen as an electron donor and ferric pyrophosphate $\left(\mathrm{Fe}-\mathrm{PP}_{\mathrm{i}}\right.$ ), ferric oxyhydrate (amorphous $\mathrm{Fe}(\mathrm{III})$ oxyhydroxide), ferric citrate, elemental sulfur, or fumarate as the sole electron acceptor (Caccavo et al. 1994; Holmes et al. 2004). Geobacter metallireducens, belonging to the Geobacteraceae family in the Deltasubdivision of Proteobacteria, was the first organism found to conserve energy from the complete oxidation of organic compounds with $\mathrm{Fe}$ (III) as the sole electron acceptor, in freshwater sediments (Lovley et al. 1987; Lovley and Phillips 1988). Shewanella species in the Gamma-subdivision of Proteobacteria are also able to reduce solid $\mathrm{Fe}(\mathrm{III})$ and are found in very diverse environments including sediments (Lovley et al. 2004). Another IRB described in the literature is Geothrix fermentans (Coates et al. 1999), which can also reduce $\mathrm{Fe}(\mathrm{III})$ under anoxic conditions. It belongs to the Acidobacteria phylum, of which only a few strains have been cultured so far including Holophag a foetida (Anderson et al. 2012).

Members of the Geobacteraceae family are often the most abundant microorganisms in aquatic sediments rich in Fe(III) (hydr)oxides (Stein et al. 2001). qPCR studies targeting members of the family Geobacteraceae $\left(1.80 \times 10^{7}\right.$ cells $\mathrm{cm}^{-3}$, assuming two gene copies per cell), Anaeromyxobacter spp. $\left(6.39 \times 10^{6}\right.$ cells cm $^{-3}$, assuming two gene copies per cell) and Shewanella spp. $\left(1.25 \times 10^{5}\right.$ cells $\mathrm{cm}^{-3}$, assuming two gene copies per cell) have shown that IRB represent about $0.2-8.7 \%$ of total bacteria in freshwater sediments (Bedard et al. 2007; Himmelheber et al. 2009; Martins et al. 2011). 


\section{Electricity generation in a sediment microbial fuel cell}

Electricity can be harvested from organic-rich aquatic sediments by electrochemically active microorganisms growing on the surface of an anode. This new application of the microbial fuel cell technology, designated as sediment microbial fuel cell (SMFC), consists of an anode embedded in the anoxic sediment and a cathode suspended in the aerobic water column connected by a resistor (Reimers et al. 2001; Martins et al. 2010). Electricity is generated by the oxidation of organic matter by microorganisms naturally present in the sediments. The oxidation of organic matter produces electrons that are captured at the anode and transferred through the external circuit to the cathode, where oxygen is typically reduced to form water. The first SMFC described in literature was operated in marine sediments due to the better ion conductivity between electrodes in saline environments (Tender et al. 2002; Bond et al. 2002). Later sediments from rivers and lakes were also used (Venkata Mohan et al. 2008; Martins et al. 2010, 2014). The main application of SMFCs is as long-term power sources for autonomous sensors and communication devices, because they can provide continuous low-level power and do not require maintenance or replacement (Tender et al. 2008; Donovan et al. 2013). The main advantage of using SMFCs is that the power generation is not limited by the fuel supply because the organic matter in the sediments is renewable. Also, the electrodes of SMFCs are inert materials, therefore the duration of power generation is not limited by the materials of construction (Donovan et al. 2013).

Nevertheless, due to various limiting factors such as substrate mass transfer limitation and low electric conductivity especially in freshwater, internal resistances in SMFC are in generally higher than those in a chamber MFC (Zhou et al. 2014; He et al. 2007). Consequently, a lower voltage and power output is obtained from a SMFC. Several attempts have been made to improve SMFC performance namely optimizing the external resistance (Song et al. 2010), improving the sediment conductivity (Babu and Mohan 2012), amendment of colloidal iron oxyhydroxide (Zhou et al. 2014), modifying the electrode materials (Fu et al. 2014), and changing the electrode configuration and assembly (Martins et al. 2014; An et al. 2013). In addition, the supply of organic matter, such as glucose, plant rhizodeposits (De Schamphelaire et al. 2010) or biomass likes chitin or cellulose
(He et al. 2007; Rezaei et al. 2008), has also been shown to increase power production.

Up to date, current output values of freshwater SMFC are not as high as those of marine SMFC due to their low conductivity (Song et al. 2012). In fact, the maximum power density values obtained in SMFCs with electrodes of felt graphite (Hong et al. 2009), carbon paper (Martins et al. 2010) and stainless steel scourer (Martins et al. 2014) are only around 4, 1 and $0.13 \mathrm{~mW} \mathrm{~m}^{-2}$, respectively. The maximum power density of SMFCs can be significantly increased by using a rotating cathode $\left(49 \mathrm{~mW} \mathrm{~m}^{-2}\right.$; He et al. 2007) or biocathode $\left(123 \mathrm{~mW} \mathrm{~m}^{-2}\right.$; De Schamphelaire et al. 2010). Another important issue is the anode-embedding depth, since as it increases, more electrons and a more negative anode potential are produced, i.e., the anode environment is thermodynamically and kinetically favorable to electroactive bacteria that can perform direct and/or indirect transfer electrons to electrodes. Therefore, the anode-embedding depth should be considered an important parameter that determines the performance of SMFC (An et al. 2013). Also a multielectrode approach could be adopted to minimize scale up losses from anode size (Hsu et al. 2013).

In sediments, the most well known electrochemically active bacteria that can transfer electrons directly from a carbon source to an anode, are Shewanella putrefaciens, a Gamma-Proteobacterium, Geobacter sulfurreducens, G. metallireducens and Desulfuromonas acetoxidans, all Delta-Proteobacteria, and Rhodoferax ferrireducens, a Beta-Proteobacterium (Logan et al. 2005; Rabaey et al. 2005; Du et al. 2007). Microbial communities associated to SMFC anodes are enriched in Delta-Proteobacteria (Bond et al. 2002; Cummings et al. 2003; Holmes et al. 2004; Reimers et al. 2006). The predominance of certain groups of bacteria is dependent upon the environment: Desulfuromonas species are more abundant in marine sediments, while in freshwater sediments Geobacter species prevail (Holmes et al. 2004).

\section{New strategy for phosphorus immobilization in sediments}

\subsection{The concept}

As mentioned above, the capacity of some metal reducing microorganisms (e.g. S. putrefaciens and $G$. 


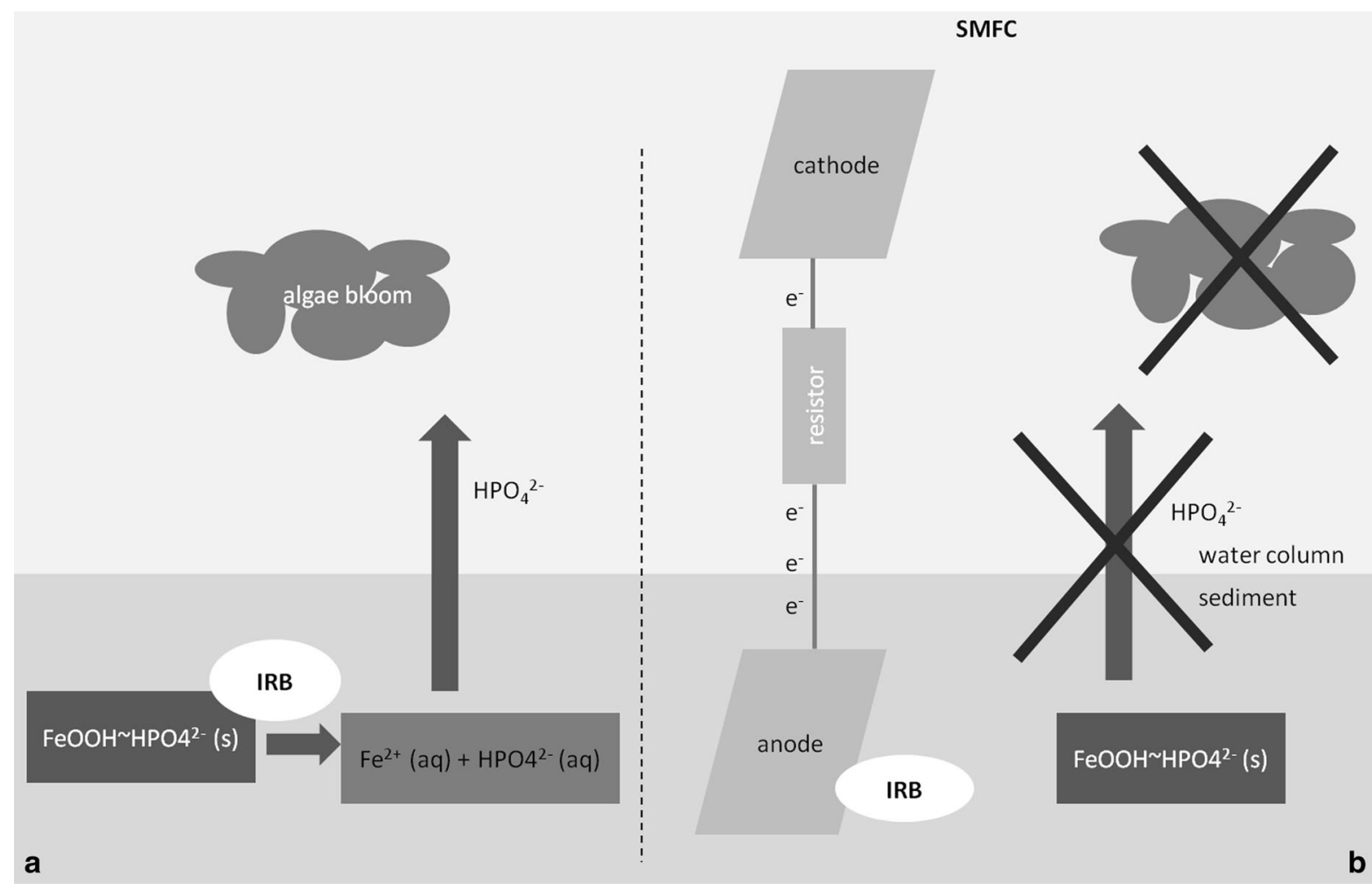

Fig. 3 Hypothetical bioremediation strategy carried out by a SMFC; $a$ reduction of iron (hydro)oxides by IRB and consequent release of $\mathrm{P}$ to the water column; $b$ adhesion of IRB to the electrode preventing the reduction of iron (hydro)oxides

sulfurreducens) to transfer electrons directly to an anode, thus generating electricity, might contribute to lake valorisation through the production of electricity (Martins et al. 2010). In addition, Martins et al. (2014) showed that in sediments impacted by the operation of SMFC (along 50 days), the metal bound $\mathrm{P}$ fraction increased $3 \%$ and the organic $\mathrm{P}$ faction decreased around $10 \%$. These results suggested that electrodes could compete with the in situ available electron acceptors. Thus, to prevent metal bound $\mathrm{P}$ dissolution under anoxic conditions, an electrode (or electrodes) needs to be inserted into sediments, in order to divert the flux of electrons devoted to Fe(III) (hydr)oxides to the surface of a anode, thereby preventing the dissolution of phosphate adsorbed by the Fe(III) (hydr)oxides. This hypothesis seems plausible; however, its implementation could be challenging (Fig. 3).

In addition, Fischer et al. (2011) have demonstrated the feasibility of reducing $\mathrm{FePO}_{4}$ in the cathodic chamber of a microbial fuel cell (MFC) with the reducing power (electrons) and protons generated during bacterial respiration. The opposite reaction, i.e. the oxidation of $\mathrm{Fe}(\mathrm{II})$ compounds forming particulate $\mathrm{Fe}(\mathrm{III})-\mathrm{P}$ compounds, would be expected to occur in the anodic chamber. Moreover, chemisorption of phosphate to the $\mathrm{Fe}$ (III) (hydr)oxides occurs at neutral $\mathrm{pH}$ and redox potential higher than $200 \mathrm{mV}$ (Wetzel 1983); thus, it should be possible to immobilize $\mathrm{P}$ into sediments controlling electrode potential.

By incorporating these findings into a new concept of lake management, the operation of a SMFC could contribute to an ecotechnological solution to phosphorus retention in lake sediments, as described in Fig. 3. However, this hypothesis has not yet been fully explored and to develop the proposed remediation technology, it is necessary to demonstrate that the electrons generated in the respiratory activity of appropriate bacteria can be diverted from $\mathrm{Fe}$ (III) (hydr)oxides to an artificial electrode as terminal electron acceptor when both are available. 


\subsection{Implementation challenges}

The rate and extent of microbial Fe(III) reduction is governed by the surface area and site concentration of the solid phase (Roden and Zachara 1996). In sediments, fine-grained minerals, such as Fe(III) oxides, and clay minerals with surficial Fe(III) (hydr)oxides have an enormous surface area and adsorb $\mathrm{P}$ efficiently on their surfaces (Lehtoranta 2004). To prevent $P$ dissolution under anoxic conditions, an electrode has to compete with these finegrained constituents of sediments as a terminal electron acceptor, meaning that electrodes with huge surface areas have to be devised.

Different electrode materials vary in their physical and chemical properties (e.g., surface area, electric conductivity, and chemical stability), thus, they also vary in their impact on microbial attachment, electron transfer, electrode resistance and the rate of electrode surface reaction. A good anode material should have (a) good electrical conductivity and low resistance, (b) strong biocompatibility, (c) chemical stability and anti-corrosion capacity, (d) large surface area, and (e) appropriate mechanical strength and toughness (Logan et al. 2006). Currently, the most versatile material is carbon, since it is available as compact material (graphite), in the form of plates, tubes or granules (filters, cloth, paper, fibers and foams), and as brushes and glassy carbon (Logan et al. 2006). Higher surface areas are achieved by the use of compact materials like reticulated vitreous carbon that are available in different porosities, and can be used in layers (Logan 2008). For example, a smaller brush anode in a cube-type MFC produced the highest power density yet achieved for an aircathode MFC, 2,400 $\mathrm{mW} \mathrm{m}^{-2}\left(73 \mathrm{~W} \mathrm{~m}^{-3}\right.$; Logan et al. 2007). In addition, the modification of graphite by adsorption of anthraquinone-1,6-disulfonic acid (AQDS) or 1,4-naphthoquinone (NQ), or a graphiteceramic composite containing $\mathrm{Mn}^{2+}$ and $\mathrm{Ni}^{2+}$, as well as the electrolytic deposition of Fe/ferric oxide were already used as strategies to increase the performance of the electrodes (Lowy et al. 2006; Fu et al. 2014).

Besides achieving the intended ecosystem remediation, it should be possible to generate some electricity. Up to now, the use of lake sediments for electricity generation has been explored in only a few studies. Martins et al. (2010) have shown that using Lake
Furnas sediments, a SMFC can generate around $6 \mathrm{~W} \mathrm{~m}^{-2}$ of electrode and per $\mathrm{m}^{3}$ of sediment. Thus, if the proposed ecotechnology were applied, it would be theoretically possible to generate $2 \mathrm{MW}$, assuming linear extrapolation to all parts of Lake Furnas. This is an indication of future prospects, but significant obstacles exist to achieve them.

\section{Conclusions and research needs}

Sediments act as an internal source of $\mathrm{P}$ to the overlying water, thus contributing to eutrophication. Several processes have been proposed to explain this phenomenon, being the $\mathrm{Fe}(\mathrm{III})$ reduction promoted by IRB one of the most important. In addition, IRB are also known to directly transfer electrons to an anode, generating electricity. Therefore, the introduction of electrodes in the sediment might contribute to diverting the flux of electrons devoted for Fe(III) reduction to the surface of a anode, thereby preventing the dissolution of phosphate. This approach could contribute to a new ecotechnological solution to $\mathrm{P}$ retention in lake sediments.

In that regard, future research should focus on the development of electrodes with huge surface areas to compete with natural iron (hydr)oxides as well as on the quantification of rates and designing experiments to understand the importance of microbial mediated pathways in P release from sediments. Additionally, researchers need to consider how biogeochemical cycles are likely to be affected by any newly discovered dissimilatory processes. Some of these novel microbial processes may prove to be tremendously valuable for the designing of new ecotechnologies for ecosystems restoration and valorisation.

Acknowledgments The authors are grateful to two anonymous reviewers of a previous version of the manuscript for the constructive comments and suggestions. The authors also acknowledge the Grant SFRH/BPD/80528/2011 from the Foundation for Science and Technology, Portugal, awarded to Gilberto Martins.

\section{References}

Altmann D, Stief P, Amann R, Beer DD (2004) Distribution and activity of nitrifying bacteria in natural stream sediment versus laboratory sediment microcosms. Aquat Microb Ecol 36:73-81 
An J, Kim B, Nam J, Ng HY, Chang IS (2013) Comparison in performance of sediment microbial fuel cells according to depth of embedded anode. Bioresour Technol 127:138-142

Anderson I, Held B, Lapidus A, Nolan M, Lucas S, Tice H, Del Rio TG, Cheng J-F, Han C, Tapia R et al (2012) Genome sequence of the homoacetogenic bacterium Holophaga foetida type strain (TMBS4(T)). Stand Genomic Sci 6(2):174-184

Azzoni R, Giordani G, Viaroli P (2005) Iron-sulphur-phosphorus interactions: implications for sediment buffering capacity in a mediterranean eutrophic lagoon (Sacca di Goro, Italy). Hydrobiologia 550(1):131-148

Babu ML, Mohan SV (2012) Influence of graphite flake addition to sediment on electrogenesis in a sediment-type fuel cell. Bioresour Technol 110:206-213

Bedard DL, Ritalahti KM, Löffler FE (2007) The Dehalococcoides population in sediment-free mixed cultures metabolically dechlorinates the commercial polychlorinated biphenyl mixture Aroclor 1260. Appl Environ Microbiol 73(8):2513-2521

Bennett EM, Carpenter SR, Caraco NF (2001) Human impact on erodable phosphorus and eutrophication: a global perspective. Bioscience 51:227-234

Bond DR, Holmes DE, Tender LM, Lovley DR (2002) Electrode-reducing microorganisms that harvest energy from marine sediments. Science 295:483-485

Bryant MP, Campbell LL, Reddy CA, Crabill MR (1977) Growth of Desulfovibrio in lactate or ethanol media low in sulfate in association with H2-utilizing methanogenic bacteria. Appl Environ Microbiol 33:1162-1169

Burgin AJ, Yang WH, Hamilton SK, Silver WL (2011) Beyond carbon and nitrogen: how the microbial energy economy couples elemental cycles in diverse ecosystems. Front Ecol Environ 9(1):44-52

Caccavo F Jr, Lonergan DJ, Lovley DR, Davis M, Stolz JF, McInerney MJ (1994) Geobacter sulfurreducens sp. nov., a hydrogen- and acetateoxidizing dissimilatory metalreducing microorganism. Appl Environ Microbiol 60:3752-3759

Canavan RW, Slomp CP, Jourabchi P, Cappellen PV, Laverman AM, Van Den Berg GA (2006) Organic matter mineralization in sediment of a coastal freshwater lake and response to salinization. Geochim Cosmochim Acta 70:2836-2855

Canfield DE, Jorgensen BB, Fossing H, Glud R, Gundersen J, Ramsing NB et al (1993) Pathways of organic-carbon oxidation in 3 continental-margin sediments. Mar Geol 113:27-40. doi:10.1016/0025-3227(93)90147-N

Carpenter SR (2005) Eutrophication of aquatic ecosystems: bistability and soil phosphorus. PNAS 102(29):10002-10005

Chacon N, Silver WL, Dubinsky EA, Cusack DF (2006) Iron reduction and soil phosphorus solubilization in humid tropical forests soils: the roles of labile carbon pools and an electron shuttle compound. Biogeochemistry 78:67-84

Chen G, White PA (2004) The mutagenic hazards of aquatic sediments: a review. Mutat Res 567:151-225

Coates JD, Ellis DJ, Gaw CV, Lovley DR (1999) Geothrix fermentans gen. nov., sp nov., a novel Fe(III)-reducing bacterium from a hydrocarbon-contaminated aquifer. Int $\mathrm{J}$ Syst Bacteriol 49:1615-1622
Conley DJ, Paerl HW, Howarth RW, Boesch DF, Seitzinger SP, Havens KE, Lancelot C, Likens GE (2009) Controlling eutrophication: nitrogen and phosphorus. Science 323:1014-1015

Cordell D, Neset TS, Prior T (2012) The phosphorus mass balance: identifying 'hotspots' in the food system as a roadmap to phosphorus security. Curr Opin Biotechnol 23:1-7

Cummings DE, Snoeyenbos-West L, Newby DT, Niggemyer AM, Lovley DR, Achenbach LA, Rosenzweig RF (2003) Diversity of geobacteraceae species inhabiting metal polluted freshwater lake sediments ascertained by $16 \mathrm{~S}$ rDNA analyses. Microb Ecol 46:257-269

Dalsgaard T, Thamdrup B, Canfield DE (2005) Anaerobic ammonium oxidation (anammox) in the marine environment. Res Microbiol 156:457-464

De Schamphelaire L, Boeckx P, Verstraete W (2010) Evaluation of biocathodes in freshwater and brackish sediment microbial fuel cells. Appl Microbiol Biotechnol 87:1675-1687

Donovan C, Dewan A, Heo D, Lewandowski Z, Beyenal H (2013) Sediment microbial fuel cell powering a submersible ultrasonic receiver: new approach to remote monitoring. J Power Sources 233:79-85

Du Z, Li H, Gu T (2007) A state of the art review on microbial fuel cells: a promising technology for wastewater treatment and bioenergy. Biotechnol Adv 25:464-482

Einsele W (1936) Über die beziehungen des eisenkreislaufs zum phosphatkreislauf im eutrophen See. Arch Hydrobiol 29:664-686

European Community (2000) Directive 2000/60/EC of October 232000 of the European Parliament and of the Council establishing a framework for community action in the field of water policy. Off J Eur Communities L327:1-72

Fennel K, Brady D, DiToro D, Fulweiler RW, Gardner WS, Giblin A, McCarthy MJ, Rao A, Seitzinger S, ThouvenotKorppoo M, Tobias C (2009) Modeling denitrification in aquatic sediments. Biogeochemistry 93(1-2):159-178

Ferry JG, Lessner DJ (2008) Methanogenesis in marine sediments. Ann NY Acad Sci 1125:147-157

Fischer F, Bastian C, Happe M, Mabillard E, Schmidt N (2011) Microbial fuel cell enables phosphate recovery from digested sewage sludge as struvite. Bioresour Technol 102:5824-5830

Fu Y, Xu Q, Zai X, Liu Y, Lu Z (2014) Low electrical potential anode modified with Fe/ferric oxide and its application in marine benthic microbial fuel cell with higher voltage and power output. Appl Surf Sci 289:472-477

Gächter R, Müller B (2003) Why the phosphorus retention of lakes does not necessarily depend on the oxygen supply to their sediment surface. Limnol Oceanogr 48(2):929-933

Golterman HL (2001) Phosphate release from anoxic sediments or 'What did Mortimer really write?'. Hydrobiologia 450(1-3):99-106

Gonsiorczyk T, Casper P, Koschel R (1998) Phosphorus-binding forms in the sediment of an oligotrophic and an eutrophic hardwater lake of the Baltic Lake District (Germany). Water Sci Technol 37(3):51-58

He Z, Shao H, Angenent LT (2007) Increased power production from a sediment microbial fuel cell with a rotating cathode. Biosens Bioelectron 22:3252-3255 
Himmelheber DW, Taillefert M, Pennell KD, Hughes JB (2008) Spatial and temporal evolution of biogeochemical processes following in situ capping of contaminated sediments. Environ Sci Technol 42:4113-4120

Himmelheber DW, Thomas SH, Löffler FE, Taillefert M, Hughes JB (2009) Microbial colonization of an in situ sediment cap and correlation to stratified redox zones. Environ Sci Technol 43:66-74

Holmer M, Storkholm P (2001) Sulphate reduction and sulphur cycling in lake sediments: a review. Freshw Biol 46:431-451

Holmes DE, Bond DR, O'Neil RA, Reimers CE, Tender LR, Lovley DR (2004) Microbial communities associated with electrodes harvesting electricity from a variety of aquatic sediments. Microb Ecol 48:178-190

Hong SW, Chang IS, Choi YS, Kim BH, Chung TH (2009) Responses from freshwater sediment during electricity generation using microbial fuel cells. Bioprocess Biosyst Eng 32:389-395

Hsu L, Chadwick B, Kagan J, Thacher R, Wotawa-Bergen A, Richter K (2013) Scale up considerations for sediment microbial fuel cells. RSC Adv 3:15947-15954

Huettel M, Røy H, Precht E, Ehrenhauss S (2003) Hydrodynamical impact on biogeochemical processes in aquatic sediments. Hydrobiologia 494:231-236

Hupfer M, Lewandowski J (2008) Oxygen controls the phosphorus release from lake sediments-a long-lasting paradigm in limnology. Int Rev Hydrobiol 93(4-5):415-432

Jeppesen E, Søndergaard M, Jensen JP, Havens K, Anneville O, Carvalho L, Coveney MF et al (2005) Lake responses to reduced nutrient loading - an analysis of contemporary long-term data from 35 case studies. Freshw Biol 50:1747-1771

Kemp WM, Sampou P, Caffrey J, Mayer M (1990) Ammonium recycling versus denitrification in Chesapeake Bay sediment. Limnol Oceanogr 35(7):1545-1563

Khoshmanesh A, Hart BT, Duncan A, Beckett R (2002) Luxury uptake of phosphorus by sediment bacteria. Water Res 36:774-778

Klueglein N, Lsekann-Behrens T, Obst M, Behrens S, Appel E, Kappler A (2013) Magnetite formation by the novel $\mathrm{Fe}$ (III)-reducing Geothrix fermentans Strain HradG1 isolated from a hydrocarbon-contaminated sediment with increased magnetic susceptibility. Geomicrobiol J 30(10):863-873

Lehtoranta J (2004) Benthic phosphorus release from sediment to water. In: Wassmann P, Olli K (eds) Drainage basin nutrient inputs and eutrophication: an integrated approach. University of Troms $\varnothing$, Norway, pp 155-166

Lentini CJ, Wankel SD, Hansel CM (2012) Enriched iron(III)reducing bacterial communities are shaped by carbon substrate and iron oxide mineralogy. Front Microbiol 3:404

Li H, Peng J, Weber K, Zhu Y (2011) Phylogenetic diversity of $\mathrm{Fe}(\mathrm{III})$-reducing microorganisms in rice paddy soil: enrichment cultures with different short-chain fatty acids as electron donors. J Soils Sediments 11(7):1234-1242

Lin B, Hyacinthe C, Bonneville S, Braster M, Van Cappellen P, Röling WFM (2007) Phylogenetic and physiological diversity of dissimilatory ferric iron reducers in sediments of the polluted Scheldt estuary, Northwest Europe. Environ Microbiol 9(8):1956-1968
Logan BE (2008) Microbial fuel cells. Wiley, Hoboken

Logan B, Murano C, Scott K, Gray ND, Head IM (2005) Electricity generation from cysteine in a microbial fuel cell. Water Res 39:942-952

Logan BE, Hamelers B, Rozendal R, Schroder U, Keller J, Freguia S, Aelterman P, Verstraete W, Rabaey K (2006) Microbial fuel cells: methodology and technology. Environ Sci Technol 40:5181-5192

Logan BE, Cheng S, Watson V, Estadt G (2007) Graphite fiber brush anodes for increased power production in air-cathode microbial fuel cells. Environ Sci Technol 41(9):3341-3346

Lovley DR, Phillips EJP (1987) Rapid assay for reducible ferric iron in aquatic sediments. Appl Environ Microbiol 53:1536-1540

Lovley DR, Phillips EJP (1988) Novel mode of microbial energy metabolism: organic carbon oxidation coupled to dissimilatory reduction of iron or manganese. Appl Environ Microbiol 54:1472-1480

Lovley DR, Stolz JF, Nord GL Jr, Phillips EJP (1987) Anaerobic production of magnetite by a dissimilatory iron-reducing microorganism. Nature 330(6145):252-254

Lovley DR, Holmes DE, Nevin KP (2004) Dissimilatory Fe(III) and $\mathrm{Mn}(\mathrm{IV})$ reduction. Adv Microb Physiol 49:219-286

Lowy DA, Tender LM, Zeikus JG, Park DH, Lovely DR (2006) Harvesting energy from the marine sediment-water interface II: kinetic activity of anode materials. Biosens Bioelectron 21:2058-2063

Martins G, Ribeiro DC, Pacheco D, Cruz JV, Cunha R, Gonçalves V, Nogueira R, Brito AG (2008) Prospective scenarios for water quality and ecological status in Lake Sete Cidades (Portugal): the integration of mathematical modelling in decision processes. Appl Geochem 23:2171-2181

Martins G, Peixoto L, Ribeiro DC, Parpot P, Brito AG, Nogueira R (2010) Towards Benthic microbial fuel cell implementation in volcanic eutrophic lakes: bacterial electrochemical activity assessment in Lake Furnas (Azores) —Portugal. Bioelectrochemistry 78:67-71

Martins G, Terada A, Ribeiro DC, Corral AM, Brito AG, Smets BF, Nogueira R (2011) Structure and activity of lacustrine sediment bacteria involved in nutrient and iron cycles. FEMS Microbiol Ecol 77:666-679

Martins G, Henriques I, Ribeiro DC, Correia A, Bodelier PLE, Cruz JV, Brito AG, Nogueira R (2012) Bacterial diversity and geochemical profiles in sediments from eutrophic Azorean lakes. Geomicrobiol J 29(8):704-715

Martins G, Brito AG, Nogueira R, Ureña M, Fernández D, Luque FJ, Alcácer C (2013) Water resources management in southern Europe: clues for a research and innovation based regional hypercluster. J Environ Manage 119:76-84

Martins G, Peixoto L, Teodorescu S, Parpot P, Nogueira R, Brito AG (2014) Impact of an external electron acceptor on phosphorus mobility between water and sediments. Bioresour Technol 151:419-423

Mortimer CH (1941) The exchange of dissolved substances between mud and water in lakes. J Ecol 29:280-329

Mortimer CH (1942) The exchange of dissolved substances between mud and water in lakes. J Ecol 30:147-201

Muyzer G, Stams AJ (2008) The ecology and biotechnology of sulphate-reducing bacteria. Nat Rev Microbiol 6(6):441-454 
Nealson KH (1997) Sediment bacteria: who's there, what are they doing, and what's new? Annu Rev Earth Planet Sci 25:403-434

Nielsen LP, Risgaard-Petersen N, Fossing H, Christensen PB, Sayama M (2010) Electric currents couple spatially separated biogeochemical processes in marine sediment. Nature 463:1071-1075

Petrie L, North NN, Dollhopf SL, Balkwill DL, Kostka JE (2003) Enumeration and characterization of iron(III)reducing microbial communities from acidic subsurface sediments contaminated with uranium(VI). Appl Environ Microbiol 69(12):7467-7479

Pettersson K (2001) Phosphorus characteristics of settling and suspended particles in Lake Erken. Sci Tot Environ 266:79-86

Pretty JN, Mason CF, Nedwell DB, Hine RE, Leaf S, Dils R (2003) Environmental costs of freshwater eutrophication in England and Wales. Environ Sci Technol 37(2):201-208

Rabaey K, Lissens G, Verstraete W (2005) Microbial fuel cells: performances and perspectives. In: Lens PN, Westermann P, Haberbauer M, Moreno A (eds) Biofuels for fuel cells: biomass fermentation towards usage in fuel cells. IWA, London, pp 377-399

Raghoebarsing AA, Pol A, Van De Pas-Schoonen KT, Smolders AJP, Ettwig KF, Rijpstra WIC, Schouten S, Damste JSS, Op Den Camp HJM, Jetten MSM, Strous M (2006) A microbial consortium couples anaerobic methane oxidation to denitrification. Nature 440:918-921

Reimers CE, Tender LM, Fertig S, Wang W (2001) Harvesting energy from the marine water interface. Environ Sci Technol 35:192-195

Reimers CE, Girguis P, Stecher HA III, Tender LM, Ryckelynck $\mathrm{N}$, Whaling P (2006) Microbial fuel cell energy from an ocean cold seep. Geobiology 4:123-136

Rezaei F, Richard TL, Logan BE (2008) Enzymatic hydrolysis of cellulose coupled with electricity generation in a microbial fuel cell. Biotechnol Bioeng 101:1163-1169

Ribeiro DC, Martins G, Nogueira R, Cruz JV, Brito AG (2008) Phosphorus fractionation in volcanic lake sediments (Azores-Portugal). Chemosphere 70:1256-1263

Roden EE, Zachara JM (1996) Microbial reduction of crystalline iron(III) oxides: influence of oxide surface area and potential for cell growth. Environ Sci Technol 30:1618-1628

Rozan TF, Taillefert M, Trouwborst RE, Glazer BT, Ma S, Herszage J, Valdes LM, Price KS, Luther GW III (2002) Iron-sulphur-phosphorus cycling in the sediments of a shallow coastal bay: implications for sediment nutrient release and benthic macroalgal blooms. Limnol Oceanogr 47:1346-1354

Selman M, Greenhalgh S (2009) Eutrophication: sources and drivers of nutrient pollution. World Resources Institute policy note, water quality: eutrophication and hypoxia no 2

Søndergaard M, Jensen JP, Jeppesen E (2003) Role of sediment and internal loading of phosphorus in shallow lakes. Hydrobiologia 506-509:135-145

Søndergaard M, Jeppesen E, Lauridsen TL, Skov C, Van Nes EH, Roijackers R, Lammens E, Portielje R (2007) Lake restoration: successes, failures and long-term effects. J Appl Ecol 44:1095-1105

Song TS, Yan ZS, Zhao ZW, Jiang HL (2010) Removal of organic matter in freshwater sediment by microbial fuel cells at various external resistances. J Chem Technol Biotechnol 85:1489-1493

Song T, Tan W, Wu X, Zhou CC (2012) Effect of graphite felt and activated carbon fiber felt on performance of freshwater sediment microbial fuel cell. J Chem Technol Biotechnol 87:1436-1440

Stein LY, La Duc MT, Grundl TJ, Nealson KH (2001) Bacterial and archaeal populations associated with freshwater ferromanganous micronodules and sediments. Environ Microbiol 3:10-18

Stockdale A, Davison W, Zhang H (2009) Micro-scale biogeochemical heterogeneity in sediments: a review of available technology and observed evidence. Earth Sci Rev 92:81-97

Tender LM, Reimers CE, Stecher HA, Holmes DE, Bond DR, Lowy DA, Pilobello K, Fertig SJ, Lovley DR (2002) Harnessing microbially generated power on the seafloor. Nat Biotechnol 20:821-825

Tender LM, Gray SA, Groveman E, Lowy DA, Kauffman P, Melhado J, Tyce RC, Flynn D, Petrecca R, Dobarro J (2008) The first demonstration of a microbial fuel cell as a viable power supply: powering a meteorological buoy. J Power Sources 179:571-575

Thamdrup B (2000) Bacterial manganese and iron reduction in aquatic sediments. In: Schink B (ed) Advances in microbial ecology, vol 16. Kluwer Academic/Plenum Publications, New York, pp 41-84

Thamdrup B, Dalsgaard T (2002) Production of N2 through anaerobic ammonium oxidation coupled to nitrate reduction in marine sediments. Appl Environ Microbiol 68:1312-1318

Thomsen U, Thamdrup B, Stahl DA, Canfield DE (2004) Pathways of organic carbon oxidation in a deep lacustrine sediment, Lake Michigan. Limnol Oceanogr 49(6):2046-2057

United Nations Environment Programme (UNEP) (2012) http://www.unep.or.jp/ietc/publications/short_series/ lakereservoirs-3/2.asp. Accessed 26 Sept 2012

Venkata Mohan S, Srikanth S, Veer Raghuvulu S, Mohanakrishna G, Kiran Kumar A, Sarma PN (2008) Evaluation of various types of aquatic eco-system potential in harnessing bioelectricity through benthic fuel cell: effect of water characteristics and electrode assembly. Bioresource Technol. doi:10.1016/j.biortech.2008.10.020

Wetzel RG (1983) Limnology, 2nd edn. Saunders College Publishing, Philadelphia

Wobus A, Bleul C, Maassen S, Scheerer C, Schuppler M, Jacobs E, Röske I (2003) Microbial diversity and functional characterization of sediments from reservoirs of different trophic state. FEMS Microbiol Ecol 46:331-347

Zhou YL, Yang Y, Chen M, Zhao ZW, Jiang HL (2014) To improve the performance of sediment microbial fuel cell through amending colloidal iron oxyhydroxide into freshwater sediments. Bioresour Technol 159:232-239 